\title{
FACTORS AFFECTING ON OBESITY AND UNDER- WEIGHT WITH OUTCOME AMONG PEOPLE LIVING IN THE VICINITY OF MARZIPURA, FAISALABAD
}

1. MBBS, FCPS (Med) Assistant Professor of Medicine Independent Medical College/ Independent University Hospital, Faisalabad

2. MBBS, MCPS, FCPS (Med) Professor and Head of Medicine Deptt.

Independent Medical College/ University Hospital, Faisalabad

Correspondence Address: Muhammad Zakria MBBS, FCPS (Med)

Assistant Professor of Medicine Independent Medical College/ Independent University Hospital, Faisalabad

zakriadr@yahoo.com

Article received on: $16 / 09 / 2014$

Accepted for publication: 05/10/2014

Received after proof reading: $17 / 10 / 2014$
Dr. Muhammad Zakria , Dr. Muhammad Ashraf²

ABSTRACT... Due to transformation in nutritional status, along with epidemiological and socio demographic changes in developing countries like Pakistan, obesity and underweight coexist in our community. Date about coexistence of obesity (body mass index, BMI $\geq 30 \mathrm{~kg} / \mathrm{m}^{2}$ ) and underweight $\left(\mathrm{BMI} \geq 18.5 \mathrm{~kg} / \mathrm{m}^{2}\right)$ and related factors are lacking in this region of our province. This study will help us to relate different sociodemographic factors with obesity and underweight. Objective: To know the prevalence of obesity and underweight by body mass index (BMI) and to investigate the association of obesity and underweight with selected health conditions and socioeconomic differences in this group. Study Design: Observational retrospective crosssectional study. Material \& Methods: The record of 1656 individual presented in medical OPD or Independent University Hospital Marzi Pura Faisalabad, during the period of 4 months Mar 2013 to June 2013 was analysed. Age, Sex, Body Weight and height were enter in a structure format sheet. Date was analysed by SPSS Version17. Results: Mean BMI was $24.0 \mathrm{~kg} / \mathrm{m}^{2}$ (SD $=6.2$ ), and was higher for women and decreased with age. Prevalence of obesity was $19.6 \%$ and was positively associated with female gender, family income, hypertension, and diabetes and inversely related to physical activity. Underweight affected $15.6 \%$ of participants mainly of age group $<25$ years and in elderly people, and was higher among women and low-income families. It was negatively associated with hypertension and diabetes and directly associated with Mycobacterium tuberculosis infection and $\geq 2$ hospitalizations in the previous 12 months. Conclusions: Both obesity and underweight were associated with increased morbidity. The association of underweight with Mycobacterium tuberculosis infection, increased hospitalization, and low family income may reflect illness-related weight loss in all age groups especially $<25$ years due to poor care in younger by family and social deprivation of elderly in this community. Aging in poverty may lead to an increase in nutritional deficiencies and health-related problems among the elderly.

Key words: $\quad$ Aging Health; Obesity; Body Mass Index

Article Citation: Zakria M, Ashraf M. Factors affecting on obesity and underweight with outcome among people living in the vicinity of Marzipura, Faisalabad. Professional Med J 2014;21(5):1063-1069.

\section{INTRODUCTION}

In developed World population obesity is a burden on health care system and his emerging as a significant threat to the health care system and resources ${ }^{1,2}$. Almost all people accumulate some fat as they get older. The present obesity epidemic is mainly due to changes in lifestyle behaviour. The growing obesity problem in humans has affected children, adults and older people $^{3}$. Basal metabolic index is an effective standard to assess the status of obesity in adults. $\mathrm{BMI}$ is an economical and non invasive tool to filter different categories of obese population to assess the magnitude of health problems ${ }^{4}$.

The developing countries are transforming in their epidemiological, demographic, and nutritional status. The old age population is currently the most rapidly growing group in various parts of the world, as sanitary facilities become better and improvement in medical field. It is estimated that by the end of next 30 years old age population will rise upto $300 \%$ in most of the developing countries, commonly in South America and Asian countries ${ }^{5}$.

Changes in diet pattern and physical activity are at a rapid pace in developing world. So problems related to extremes of weight such as obesity and underweight are likely to be present, as are other health problems ${ }^{6}$. In Pakistan, like other developing countries, there is major disparity in socioeconomic conditions in living community. As a matter of fact, prevalence of malnutrition and 
obesity has been noticed in a very low-income population in South American region ${ }^{7}$. In addition, there is an upward trend in number of patients with obesity in three Brazilian surveys conducted between 1973 and 1996.

There is a direct relationship between body mass index and mortality ${ }^{9,10}$. In developed world epidemiological research on mortality points in relation to body mass index suggest that the "favorable" BMI gradually increases with age, with no consistent variation between both genders ${ }^{10,11}$.

Independent Medical College/ Independent University Hospital has recently been established. It has a very wide catchment area with socioeconomic disparity (both poor, middle and high gentry class) i.e, Marzipura, Faisalabad main city, and adjoining areas of Chiniot, Narwala Bangla and different chaks from Narwala bypass. In this setting the exact statics in this area of our province are lacking. The objectives of this study were as follows.

- To know the prevelance of obesity and underweight by body mass index (BMI) in a large sample of population in Marzipura and adjoining areas.

- To investigate the relation of obesity and underweight with selected health conditions and socioeconomic differences in this group.

\section{MATERIALS AND METHODS}

For measuring obesity and under-weight, the BMI was used as the ratio of body weight (in kgs) to body height (in $\mathrm{m}^{2}$ ). Although, BMl dependent on sex and age, as a measure of body fatness, ${ }^{12}$ it is the only measure available. BMl is a simple method of screening for weight categories, ${ }^{4}$ as well as it is also cheap.

The National Institutes of Health (NIH) define BMI as normal if it is between 18.5-24.9. Underweight if $\mathrm{BMl}$ is below 18.5. Overweight if $\mathrm{BMI}$ is 25-29.9. Obesity is considered if $\mathrm{BMI}$ is $>30$ and further divided into 3 classes. 30 - 34.9 (class I obesity), 35-39.9 (class II obesity) and > 40 (class III extreme obesity) ${ }^{13}$.

\section{Study design}

An observational retrospective cross-sectional study.

\section{Setting and Duration}

This study was conducted from Mar 2013 - June 2013 on patients who came in Medical OPD of Independent University Hospital, Marzipura , Faisalabad.

\section{Sampling Technique \\ Convenient sampling}

\section{Sample size and criteria}

A total of 1656 individuals are included in this study with following criteria.

\section{Inclusion criteria}

Individuals aged $\geq 14$ years of either sexes.

\section{Exclusion criteria}

Individuals aged less than 14 years of either sex and pregnant females.

\section{Data collection and analysis procedure}

Every Individual came in Medical OPD during this period were examined. An occupational nurse noted age, sex, body weight and height of every individual. Data was entered in a structured format sheet. Then the data were analyzed through SPSS Version 17.

\section{RESULTS}

In our study, 1656 individuals were reviewed, during the period of four months (from March 2013 to June 2013). The most common age group was between $25-40$ yrs (32.6 \%), followed by between 40-55yrs (31\%), < 25yrs (23.0\%), between 55-70 yrs $(11.5 \%)$, between $70-85$ yrs (1.7\%) and > 85 yrs were only $0.2 \%$. Female was dominated i.e, 1094 (66.06 \%) against male gender i.e, 562 (33.94\%) as shown in Table I.

Table-II. shows distribution of BMI $(\mathrm{kg} / \mathrm{m} 2)$ for both gender by age group. Mean total BMI was $24.0 \mathrm{~kg} / \mathrm{m} 2$ (SD = 6.2). As the age increased, BMI was significantly decreased particularly in males. 


\begin{tabular}{|c|c|c|c|c|c|}
\hline & Age Group & \multicolumn{2}{|c|}{ Sex } & Total & \%age \\
\hline \multirow{4}{*}{ Age } & Less than 25 & 252 & 129 & 381 & 23.0 \\
\hline & $25-40$ & 396 & 144 & 540 & 32.6 \\
\hline & $40-55$ & 328 & 185 & 513 & 31.0 \\
\hline & Greater or Equal to 85 & 0 & 4 & 4 & 0.2 \\
\hline \multicolumn{2}{|r|}{ Total } & 1094 & 562 & 1656 & 100.0 \\
\hline
\end{tabular}

\begin{tabular}{|l|c|c|c|}
\hline \multicolumn{1}{|c|}{ Age } & \multicolumn{3}{|c|}{ BMI } \\
\cline { 2 - 4 } Male & Minimum & Maximum & Mean (SD) \\
\hline Less than 25 & 13.2 & 42.5 & $23.9(5.6)$ \\
\hline 25 - 40 & 13.3 & 44.9 & $23.5(5.5)$ \\
\hline $40-55$ & 14.6 & 43.5 & $23.0(5.4)$ \\
\hline $55-70$ & 13.1 & 36.9 & $24.2(6.1)$ \\
\hline $70-85$ & 16.2 & 32.4 & $22.7(4.8)$ \\
\hline Greater than 85 & 14.7 & 33.0 & $21.1(8.4)$ \\
\hline Female & & & \\
\hline Less than 25 & 11.0 & 47.0 & $25.1(6.5)$ \\
\hline 25-40 & 13.0 & 52.0 & $25.6(6.5)$ \\
\hline $40-55$ & 11.0 & 47.0 & $25.1(6.1)$ \\
\hline $55-70$ & 14.0 & 43.0 & $26.16 .5)$ \\
\hline $70-85$ & 15.0 & 34.0 & $24.3(6.4)$ \\
\hline Greater than 85 & -- & -- & -- \\
\hline Table-II. Distribution of BMI by age and gender \\
\hline
\end{tabular}

More over it was higher for female than males.

A total of 258 (15.6\%) individuals were underweight $\left(\mathrm{BMI} \leq 18.5 \mathrm{~kg} / \mathrm{m}^{2}\right)$ and 324 (19.6\%) were obese (BMI $\left.\geq 30 \mathrm{~kg} / \mathrm{m}^{2}\right)$. (Table-III).

The prevalence of obesity decreased with increasing age. Obesity was particularly more common in females. But statistically, this decrease in BMI was only important among female, but similar for both genders after the age of 70 years. In contrast with underweight, different research reveals that obesity is more common in high income family and people with high level of education.

\begin{tabular}{|c|c|c|}
\hline \multicolumn{3}{|c|}{ BMI } \\
\hline BMI & Frequency & \%age \\
\hline <18.5 (under-weight) & 258 & 15.6 \\
\hline 18.5-24.9 (Normal) & 673 & 40.6 \\
\hline 25-29.9 (Over-weight) & 401 & 24.2 \\
\hline 30-34.9 (Obese - C-I) & 223 & 13.5 \\
\hline 35-39.9 (Obese - C-II) & 73 & 4.4 \\
\hline$>40$ (Obese -C-III) & 28 & 1.7 \\
\hline Total & 1656 & 100.0 \\
\hline \multicolumn{3}{|c|}{$\begin{array}{l}\text { Table-III. Frequency and percentage of BMI } \\
\text { (Prevalence of underweight and Obesity) }\end{array}$} \\
\hline
\end{tabular}

Underweight was also significantly more common among females than male. An increase was observed after the age of 25 years and in elderly people. On the other hand, prevalence of underweight was statistically, very important in people with minimum income. There was also downward trend with respect to age and gender.

As far as, the associations of obesity and malnutrition with the factors presented in Table IV and $V$ was concerned, there were no significant gender variations. Therefore, the results of multiple variables analysis are presented together and adjusted for gender.

Results of multiple variables analysis of underweight and obesity in relation to different social-demographic factors like life-style, and different health conditions are shown in table-IV. More importantly, obesity was directly related and associated with sedentary life style, hypertension, and diabetes. But was negatively related to anemia. Underweight was inversely related to hypertension and diabetes. It was more common 


\begin{tabular}{|c|c|c|c|}
\hline Factor & Reference group ( $n-1656)$ & Underweight $(n=258)$ & Obesity $(n=324)$ \\
\hline $\begin{array}{l}\text { Gender } \\
\text { Male } \\
\text { Female }\end{array}$ & $\begin{array}{c}562 \\
1094\end{array}$ & $\begin{array}{l}124(48 \%)---(47 \%) \\
134(52 \%)-(53 \%)\end{array}$ & $\begin{array}{c}65(20 \%)--(19 \%) \\
259(80 \%)-(81 \%)\end{array}$ \\
\hline $\begin{array}{c}\text { Age group years } \\
<25 \\
25-40 \\
40-55 \\
55-70 \\
70-85 \\
85+\end{array}$ & $\begin{array}{c}381 \\
540 \\
513 \\
190 \\
28 \\
4\end{array}$ & $\begin{array}{l}122 \\
65 \\
29 \\
38 \\
3 \\
1\end{array}$ & $\begin{array}{c}109 \\
110 \\
85 \\
15 \\
5 \\
0\end{array}$ \\
\hline $\begin{array}{l}\text { Smoker } \\
\text { Never } \\
\text { Former } \\
\text { Current }\end{array}$ & $\begin{array}{l}855 \\
384 \\
417\end{array}$ & $\begin{array}{c}75 \\
43 \\
140\end{array}$ & $\begin{array}{l}212 \\
84 \\
28\end{array}$ \\
\hline $\begin{array}{c}\text { Physical inactivity } \\
\text { No } \\
\text { Yes }\end{array}$ & $\begin{array}{c}1324 \\
332\end{array}$ & $\begin{array}{l}154 \\
104\end{array}$ & $\begin{array}{l}203 \\
121\end{array}$ \\
\hline $\begin{array}{c}\text { Salary } \\
<10000 \\
10000-30000 \\
>30000\end{array}$ & $\begin{array}{c}994 \\
570 \\
92\end{array}$ & $\begin{array}{c}133 \\
112 \\
13\end{array}$ & $\begin{array}{c}188 \\
110 \\
26\end{array}$ \\
\hline $\begin{array}{l}\text { Dietary habits } \\
>3 \text { meals a day } \\
3 \text { meals a day } \\
<3 \text { meals a day }\end{array}$ & $\begin{array}{l}159 \\
975 \\
522\end{array}$ & $\begin{array}{c}24 \\
154 \\
80\end{array}$ & $\begin{array}{c}55 \\
147 \\
122\end{array}$ \\
\hline $\begin{array}{c}\text { Hypertension } \\
\text { No } \\
\text { Yes }\end{array}$ & $\begin{array}{c}629 \\
1027\end{array}$ & $\begin{array}{l}138 \\
120\end{array}$ & $\begin{array}{c}72 \\
252\end{array}$ \\
\hline $\begin{array}{c}\text { Diabetes } \\
\text { No } \\
\text { Yes }\end{array}$ & $\begin{array}{c}1407 \\
249\end{array}$ & $\begin{array}{c}207 \\
51\end{array}$ & $\begin{array}{c}242 \\
82\end{array}$ \\
\hline $\begin{array}{l}\text { Anemia } \\
\text { No } \\
\text { Yes }\end{array}$ & $\begin{array}{c}1518 \\
138\end{array}$ & $\begin{array}{c}232 \\
26\end{array}$ & $\begin{array}{c}322 \\
2\end{array}$ \\
\hline $\begin{array}{c}\text { Mycobacterium tuberc } \\
\text { sis infection } \\
\text { No } \\
\text { Yes }\end{array}$ & $\begin{array}{l}993 \\
663\end{array}$ & $\begin{array}{l}121 \\
137\end{array}$ & $\begin{array}{c}282 \\
42\end{array}$ \\
\hline
\end{tabular}

among smokers and especially those people who were smoking currently. Mycobactrium Tuberculosis infection and anemia were also more common in underweight individuals.

Table $\mathrm{V}$ shows that obese people rate their health poor/very poor than those in the reference $\mathrm{BMI}$ category. Statistically, this difference was interestingly not significant for underweight individuals. It also showed that hospitalizations during last 12 months, were reported more by underweight individuals. While obese persons reported more doctor visits during the last 12 months.

\section{DISCUSSION}

Study shows that in over community the prevalence of obesity is slightly more than the people with under-weight. As far as age and sex are concerned result shows that obesity as well as under-weight are similar to the results of studies in other parts of the world ${ }^{10,14}$.

Obesity is a big issue now a days in the developing 


\begin{tabular}{|c|c|c|c|}
\hline Factors & Reference Group (n-1656) & Underweight (n-258) & Obesity $\mathbf{( n - 3 2 4 )}$ \\
\hline Visit to GP in last 12 months & & 48 & 38 \\
None & 311 & 52 & 76 \\
1 & 351 & 158 & 210 \\
$2+$ & 994 & & 256 \\
\hline Admission to hospital in last 12 & & 1088 & 47 \\
months & 1324 & 331 & 21 \\
None & 249 & 237 & 68 \\
$2+$ & 83 & & 160 \\
\hline
\end{tabular}

Table-V. Doctor visits And hospitalization with self-related health opinion

countries, just like in our society also. It has variable pattern in different geographic regions and high in females living in city area instead of villages. In our study, people with obesity in adult population has the prevalence to other parts of the world i.e. in European population, united states $^{15,16}$ and in India ${ }^{2}$. However, in difference to developed world, in old age population obesity was more common among higher income group as compared to low income population ${ }^{17}$.

Association of obesity with high income population has been shown in other developing communities $^{19}$ as well as in other countries like United States and Brazil ${ }^{16,18}$. In China as well as in India, people living in cities especially with high income are with obesity problems due to high fat in there diet ${ }^{20,21}$. Overweight among high income people appear first than among no income classes. The main causes include decrease physical activity as well as nutritional change to high fat die.

In our study, hypertension and diabetes mellitus is directly proportionate to obesity. It is positively associated with hypertension and diabetes. Obesity is a complex metabolic disorder frequently associated with insulin resistance, hyper-insulinemia, increased atherosclerosis, hypertension, and diabetes type $\|^{22}$. The association between obesity and decreased physical activity is present in other studies also. Decreased physical activity leads to decreased calorie burn which causes increased calorie reserve leading to our weight and later on obesity $^{23}$. However, the relative risk of death with excessive body fat in old population is for less than in younger adults ${ }^{24}$. Actually, epidemiological studies do not support overweight $(\mathrm{BMI}=25$ $\left.29 \mathrm{~kg} / \mathrm{m}^{2}\right)$, as opposed to obesity $\left(\geq 30 \mathrm{~kg} / \mathrm{m}^{2}\right)$, as conferring an excess mortality risk to the elderly ${ }^{24}$.

Obese old age population reported more visits to GP and believed their health status lesser than those with weight within normal range. It has been seemed that health problems are more among obese people and they also rate there health status as poor or at the most fair as for as they concerned ${ }^{14}$. As a matter of fact these factors explain the similar feeling of deteriorating and trend of modern society to invariably condemn obesity.

In our study, families who earn more or equal to 30,000 rupees monthly have obesity problem and are similar other study results ${ }^{25}$. James et al. showed that in United States people earning US $\$ 600$ or more monthly have similar problem. Prevalence of underweight is directly proportionate to low income families. Malnutrition lead to decreased physical strength decreased activities, high accidents risk and there immune system also become weak especially in elderly along with other health problems $26,27,17$.

In our study, people with underweight admitted more in hospitals profthat they have ill health condition especially in old age. Elderly people are usually dependent and more neglected in our community suffering from different nutritional deficiencies. Protein-energy malnutrition appears 
to be a strong independent risk factor for nonelective hospital readmission, especially among the highest-risk patients, those who are elderly and functionally independent and cognitively intact ${ }^{26}$. It has been argued that the inverse association of weight and mortality in old age is related to smoking and reflects illness-related weight loss ${ }^{28}$. In a longitudinal study, elderly women with lower energy intake than recommended by international organizations in 1980 were three times more likely to die in 10 years than those with satisfactory energy intake ${ }^{9}$.

Nutritional deficiencies lead to different infections and chronic disease. In our community, tuberculosis infection is more common due to poor sanitary facilities. In Brazilian population, Chagas disease due to T. cruzi infection ${ }^{29}$ is more common in elderly underweight people.

The cut-points that we used to define underweight and obesity may be conservative. A meta-analysis of the relationship between body weight and allcause mortality has identified an increased risk of death among older adults with $\mathrm{BMI}<23$ or $>$ $28 \mathrm{~kg} / \mathrm{m}^{2} 30$.

In our study we have shown that body mass index is directly proportionate to economic status, as in studies from developed countries ${ }^{14,15}$. A similar relationship has also been reported from India and this tends to express the massive socioeconomic variability present in most of developing nations ${ }^{2}$. The economic variability between developed and under-developed countries is widening. Meanwhile, in developing countries like Pakistan, disparity in income is rising as in others parts of the world ${ }^{6}$. Pakistan is one of the countries with the major socioeconomic inequalities. People under age of 25 years and elderly people are mostly suffering from nutritional abnormalities. Even considering that age is increasing all the time in both groups high income and low income. The association of aging with low income group may lead to increase in metabolic and nutrition diseases in old age population.

Copyright@ 23 Sep, 2014.

\section{REFERENCES}

1. Gortmaker SL et al. Changing the future of obesity: science, policy and action. Lancet. 2011 Aug 27;378(9793):838-47.

2. Zargar, A. H.; Masoodi, S. R.; Laway, B. A.; Khan, A. K.; Wani, A. I.; Bashir, M. I. \& Akhtar, S., 2000. Prevalence of obesity in adults - An epidemiological study from Kashmir Valley of Indian Subcontinent. Journal of the Association of Physicians of India, 48:1170-1174.

3. Parveen Kumar, Michael Clark et al. Nutrition, Kumar \& Clark's Clinical Medicine- 8th Edition 2012,Chapter 5: 195-227.

4. Centers for Disease Control and Prevention 1600 Clifton Rd. Atlanta, GA 30333, USA 800-CDC-INFO (800-232-4636) TTY: (888) 232-6348-cdcinfo@cdc.gov.

5. TRUELSEN, T.; BONITA, R. \& JAMROZIK, K., Surveillance of stroke: A global perspective. International Journal of Epidemiology, 2001;30:S11-S16.

6. DARNTON-HILL, I. \& COYNE, E. T., Feast and famine: Socio-economic disparities in global nutrition and health. Public Health Nutrition, 1998;1:23-31.

7. Florêncio, T M.; Ferreira, H. S.; Franca, A. P.; Cavalcante, J. C. \& Sawaya, A. L., Obesity and undernutrition in a very low-income population in the city of Maceió, Northeastern Brazil. Brazilian Journal of Nutrition, 2001;86:277-284.

8. LOTUFO, P. A., Increasing obesity in Brazil: Predicting a new peak of cardiovascular mortality. São Paulo Medical Journal, 2000;118:161-162.

9. Vellas, B. J.; Hunt, W. C.; Romero, L. J.; Koehler, K. M.; Baumgartner, R. N. \& Garru, P. J., 1997. Changes in nutritional status and patterns of morbidity among free-living elderly persons: A 10-year longitudinal study. Nutrition, 13:515-519.

10. Visscher, T. L.; Seidell, J. C.; Menotti, A.; Blackburn, H.; Nissinen, A. \& Feskens, E. J. \& Kromhout, D., Underweight and overweight in relation to mortality among men aged 40-59 and 50-69 years: The seven countries study. American Journal of Epidemiology, 2000;151:660-666.

11. King $D E$ et al. Adherence to healthy lifestyle habits in US adults, 1988-2006. Am. J Med. 2009 Jun;122(6):52834.

12. Ref : 12. Gallagher D, Vrsser M, Sepulveda D, Pierson RN, Harris T, Heumsfield SB. How useful is body mass index for comparison of body fatness across age, sex, and ethnic groups? Am J Epidemiol 1996;143:22839.

13. Robert B. Baron, MD MS Current Med Diagnosis- 
2013. Ch. 29 Nutritional Disorders page 1258-1261.

14. Ostbye, T.; Pomerleau, J.; Speechley, M.; Pederson, L. L. \& Speechley, K. N., 1995. Correlates of body mass index in the 1990 Ontario Health Survey. Canadian Medical Association Journal, 152:811-817.

15. Seidell, J. C. \& Flegal, K. M., Assessing obesity: Classification and epidemiology. British Medical Bulletin, 1997;53:238-252.

16. Christie A, Befort PhD,Niaman Nazir MD, Michael G. Perri PhD. Prevalence of Obesity Among Adults From Rural and Urban Areas of the United States: Findings From NHANES (2005-2008). The journal of Rural Health. Vol. 28, Issue 4,pages 392-397, Autumn 2012.

17. James, W. P.; Nelson, M.; Ralph, A. \& Leather, S., 1997. Socio-economic determinants of health. The contribution of inequalities in health. BMJ, 1997;314:1545-1549.

18. Monteiro, C. A.; Conde, W. L. \& Popkin, B. M., 2001. Independent effects of income and education on the risks of obesity in the Brazilian adult population. Journal of Nutrition, 131:881S-886S.

19. Arantxa Colchero Benjamin Caballerob, David Bisharia. The effect of income and occupation on BMI among women in the Cebu Longitudinal Health and Nutrition Surveys (1983-2002). Department of Health Eco Social Science \& Medicine Vol 66, Issue 9 , May 2008, pages 1967-1978.

20. Mehta, P. \& Shringarpure, B., Diet nutrition and health profile of elderly population of urban Baroda. Indian Journal of Public Health, 2000;44:124-128.

21. Popkin, B. M.; Keyou, G.; Zhai, F.; Guo, X.; MA, H. \& Zohoori, N., The nutrition transition in China: A cross-sectional analysis. European Journal of Clinical Nutrition, 1993;47:333-346.

22. Bays HE, Chapman R.H., Grandy V. The relationship between BMI to Diabetes Mellitus, Hypertension and
Dyslipidemia: comparison of data from two national surveys. The authors AstraZeneca Pharmaceuticals LP Int J Clin Pract, May 2007. 61,5,737-747.

23. Kaphingst KA, Bennett GG, Sorensen G, Kaphingst KM, Neil AEO and Mclnnis K. Body mass index, physical activity and dietary behaviours among members of an urban community fitness center: a questionnaire survey BMC Public Health 2007, 7:181.

24. Heiat, A.; Vaccarino, V. \& Krumhols, H. M., 2001. An evidence-based assessment of Federal Guidelines for overweight and obesity as they apply to elderly persons. Archives of Internal Medicine, 2001;161:11941203.

25. Sattar A et al. Factors affecting BMI; Assesment of the effect of sociodemographic factors on BMI in the population of GMAbad, FSD. Professional Med J 2013;20(6):956-964.

26. Milne $A C$ et al. Protein and energy supplementation in elderly people at risk from malnutrition. Cochrane Database Syst Rev. 2009 Apr 15;(2):CD003288.

27. Chandra, R. K., Nutrition and immunoregulation. Significance for host resistance to tumours and infectious diseases in humans and rodents. Journal of Nutrition, 1992;122(Sup.):754-757.

28. Chhabra P, Chhabra SK. Effect of smoking on BMI: a community-based study. National Journal of Community Medicine Vol 2 Issue 3 Oct-Dec 2011.

29. Lima-Costa, M. F. F.; Barreto, S. M.; Guerra, H. L.; Firmo, J. O. A.; Uchoa, E. \& Vidigal, P. G., 2002. Ageing with Trypanosoma cruzi infection in a community where the transmission has been interrupted: The Bambuí Health and Ageing Study (BHAS). International Journal of Epidemiology, 30:887-893.

30. Troiano, R. P.; Frongillo Jr., E. A.; Sobal, J. \& Levitsky, D. A., The relationship between body weight and mortality: A quantitative analysis of combined information from existing studies. International Journal of Obesity and Related Metabolic Disorders,1996;20:63-75. 